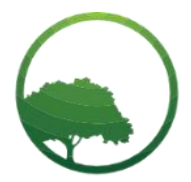

Research in Business \& Social Science

IJRBS VOL 10 NO 8 ISSN: 2147-4478

\title{
Clan-type organizational culture in the food and beverage industry in Jambi province
}

\author{
(D) Said Almaududi (a)* (D) Sihol Situngkir (b) (D) Edward (c) (D) Shofia Amin ${ }^{(d)}$ \\ (a) Doctoral Student at Jambi University, Indonesia \\ (b) Professor at Jambi University, Indonesia \\ ${ }^{(c, d)}$ Lecturer at Jambi University, Indonesia
}

A R T I C L E I N F O
Article history:
Received 07 December 2021
Received in rev. form 24 Dec. 2021
Accepted 27 December 2021
Keywords:
Organizational culture, managerial
competence, affective commitment,
performance
JEL Classification:
O15

\begin{abstract}
A B S T R A C T
This research is a study that analyzes and explains the influence model of organizational culture, managerial competence on performance mediated by the affective commitment and its implications for the food and beverage industry in Jambi Province. The sample of this study used the probability sampling technique. The sample selection criteria were the food and beverage industry players as many as 343 samples were obtained from 2 districts, namely Sarolangun, Kerinci, and Jambi city. Data analysis was performed using descriptive statistical analysis and inferential statistical analysis. The data obtained were processed using a component-based or variance-based Structural Equation Modeling (SEM) causality analysis which is known as Partial Least Square (PLS). The results showed that the direct influence of organizational culture, managerial competence and affective commitment had a positive and significant effect on the performance of food and beverage industry business actors, and the indirect influence of organizational culture and managerial competence on performance mediated by affective commitment also had a positive and significant effect. The results of this study indicate that organizational culture is dominated by the clan type which has the character of kindship and togetherness has an influence on the performance of business actors in the food and beverage industry in Jambi Province.
\end{abstract}

\section{Introduction}

The food and beverage industry in Jambi Province was also affected by the COVID-19 pandemic, a small-scale research was conducted to determine the response of the food and beverage industry players, the small-scale survey took a sample of 52 people, besides that the business capital owned by respondents was below 50 million and the average self-owned business capital, the distribution of the sample is taken in the city of Jambi and its surroundings

The impact experienced by the food and beverage industry players, from the table reflects the influence of the COVID-19 pandemic on the operational activities of the food and beverage industry players in Jambi Province, from the table it can be concluded that the COVID-19 pandemic has had a very negative impact on all internal aspects. business actors such as a $98 \%$ decrease in income, $69 \%$ laying off employees, and more than 74\% discontinuing business activities, besides that external aspects were also affected such as $52 \%$ lack of smooth marketing, $83 \%$ need for fund injections and lack of smooth business loan payments. by $62 \%$.

During the COVID-19 pandemic, the organizational culture that has been formed so far has resulted in several government policies issued during the pandemic, the company must start to be friendly and make adjustments to current conditions. Building a strong

\footnotetext{
* Corresponding author. ORCID ID: 0000-0003-1230-6018

(C) 2021 by the authors. Hosting by SSBFNET. Peer review under responsibility of Center for Strategic Studies in Business and Finance.

https://doi.org/10.20525/ijrbs.v10i8.1511
}

Citation: Almaududi, S., Situngkir, S., Edward, E., \& Amin, S. (2021). Clan-type organizational culture in the food and beverage industry in Jambi province. International Journal of Research in Business and Social Science (2147- 4478), 10(8). 
organizational culture that is relevant to current conditions is one of the most effective ways to be able to adapt to the development of pandemic conditions so that the company has sufficient capabilities. The hope is to stay ahead and be able to compete in times of high uncertainty. Culture always adapts to changes that occur around it (Rochim and Sutoyo, 2020)

Organizational culture is the group's desire to act according to the expectations and manifestations of life in achieving the values adopted by the organization. Building an effective organizational culture during the current pandemic, it is necessary to make adjustments, in connection with the many changes that occur in the order of life, starting from social life and also in organization. The impact of the policy by maintaining a distance or social distancing, has changed the pattern of behavior in everyday life. Even the way of working has been replaced by online or virtual ways to prevent the spread of the COVID-19 pandemic. Thus, how adjustments must be made to the organizational culture. Where and what are the cultural elements that have the most important role in the organization during the COVID-19 pandemic? This is the question that arises in every manager's mind. Where do you want to take the company organization that has been the mainstay of many people in the economic sector? In addition to organizational culture, another factor, namely commitment, has also become an important concern in many studies because it has a significant impact on work behavior such as organizational performance (Rochim and Sutoyo, 2020). Zwell (2000) suggests that the organization can be said to have good performance due to several factors, namely competence in terms of leadership, competence in terms of employees and organizational/company culture that strengthens and maximizes these competencies, in addition Wibowo (2011) suggests that giving emphasis on the important role culture within an organization/company, states that the work/performance of the company/organization is largely determined by the existence of an organizational culture and the culture of all human resources within the organization. In addition, in the research of Kotter and Haskett (1992) in their research, they explain the fact that a strong culture will affect the overall performance of the organization/company.

In Indonesia, MSMEs have a significant contribution and role, including expanding employment opportunities. MSMEs are also the most important safety net for low-income people to carry out productive economic activities. Besides that, small, micro and medium enterprises (MSMEs) are types of businesses that have an important role in increasing the GDP (Gross Domestic Income) of a country, especially in Indonesia in facing the Industrial Era 4.0.

The COVID-19 pandemic in Indonesia was first detected on March 2, 2020, when 2 people were confirmed to have contracted it from a Japanese citizen . As of April 9, the pandemic had spread to 34 provinces with East Java, DKI Jakarta and South Sulawesi as the most exposed provinces. Efforts to prevent the spread were carried out and campaigned. There are at least two ways that are key to controlling the transmission and spread of COVID-19, namely by maintaining distance and diligently washing hands with soap and increasing portable sinks which are held independently by the community. The government finally implemented Large-Scale Social Restrictions (PSBB) and campaigned for Stay at home. The MSME sector was also badly affected. Based on data from the cooperatives ministry, which explained that 1,785 cooperatives and 163,713 Micro, Small and Medium Enterprises (MSMEs) were affected by the coronavirus pandemic (Antara, May 2020). The MSME sector most affected is food and beverage.

The Ministry of Cooperatives and MSMEs said that cooperatives engaged in services and production were also the most affected by the COVID-19 pandemic. MSME entrepreneurs feel the decline in sales, lack of capital, and hampered distribution. At least 39.9 percent of MSMEs decided to reduce the stock of goods during the large-scale social restrictions (PSBB) due to COVID19. Meanwhile, 16.1 percent of MSMEs chose to reduce employees due to closing physical stores. The MSME sector has been seriously impacted by the COVID-19 pandemic.

The Indonesian Institute of Sciences (LIPI) conducted a Rapid Assessment Survey on the Impact of the COVID-19 Pandemic on the Performance of Indonesian MSMEs conducted online on 1-20 May 2020, and involved 679 valid respondents with the main livelihood as business actors. The food and beverage industry in Jambi Province also affected by the COVID-19 pandemic, a smallscale research was conducted to find out the response of the food and beverage industry players, the small-scale survey took a sample of 52 people, besides that the business capital owned by the respondents was below 50 million and the average business capital was owned by themselves, the distribution of samples taken in the city of Jambi and its surroundings.

The impact of the COVID-19 pandemic has also resulted in the organizational culture that has been formed so far, with several government policies issued during the pandemic, companies must start to be friendly and make adjustments to current conditions. Building a strong organizational culture that is relevant to current conditions is one of the most effective ways to be able to adapt to the development of pandemic conditions so that the company has sufficient capabilities. The hope is to stay ahead and be able to compete in times of high uncertainty. Culture always adapts to changes that occur around it (Rochim and Sutoyo, 2020)

In every organization, both large and small organizations have a culture that has been formed since the founding of the organization, culture can also be reflected in the organization's regulations in carrying out its operational activities which end in organizational performance, the character of the leader also has a very important role in the performance of the organization under its control. delegate to operational managers, in the operational activities of the food and beverage industry, the ability and character of managers in managing subordinates and empowering all sources in an effort to achieve the expected profit can also create a positive organizational culture in supporting the continuity of the food and beverage industry business. 
This research approach uses the object of the food and beverage industry that discusses organizational culture and managerial competence with affective commitment as a mediator to determine the work of the food and beverage industry. For this reason, some very basic questions will be raised as follows:

i. How is the influence of organizational culture on the performance of the food and beverage industry in Jambi Province?

ii. How is the influence of managerial competence on the performance of the food and beverage industry in Jambi Province?

iii. How does affective commitment affect the performance of the food and beverage industry in Jambi Province?

iv. How is the influence of organizational culture on the performance of the food and beverage industry mediated by affective commitment to the food and beverage industry in Jambi Province?

v. How is the influence of managerial competence on the performance of the food and beverage industry mediated by affective commitment to the food and beverage industry in Jambi Province?

\section{Literature Review}

\section{Theoretical and Conceptual Background}

The main theory in this study is the theory of human resource management (Human Resource Management) which refers to all activities in organizations that effectively use human resources, where these activities include human resource planning, staffing , performance management, training and development, compensation and industrial relations (Dowling et al, 2013). A more specific discussion is carried out on the theory between middle-range theory, namely organizational behavior.

Organizational behavior is a study concerning aspects of human behavior in an organization or a particular group. The first aspect includes the influence of organizations on humans, while the second aspect is the influence of humans on organizations in which it explains the interactions and relationships between organisms on the one hand and individual behavior on the other. The unit of analysis in organizational behavior consists of individuals, groups and organizational systems. All of them have a practical purpose, namely to direct human behavior towards efforts to achieve goals. Organizational behavior is a field of study that examines the impact of individuals, groups and structures on organizational behavior with the aim of increasing organizational effectiveness (Robbins, 2006).

Organizational behavior is actually formed from the behavior of individuals in the organization. Therefore, as mentioned above, the study of organizational behavior problems clearly includes or involves the discussion of individual behavior. Thus it can be seen that the scope of the study of organizational behavior is limited to the internal dimensions of an organization. In this regard, aspects that become elements, components and subsystems of organizational behavior science include organizational culture, managerial competence, affective commitment and performance.

Organizational culture is a system of beliefs and beliefs and values that grow and develop in organizations (Wood et al, 1994), from the many definitions of organizational culture put forward by experts, this study tries to apply the types of organizational culture described by Cameron and Quinn (2011) which divides the organization into four categories namely, Clan, Adhocrachy, Market and Hierarchy, in addition to the types of organizational culture, managerial competencies proposed by Cameron and Quinn are also applied in this study, then this research also applies the performance of small and medium industries. Hudson's medium that focuses on the food and beverage industry is mediated by affective commitment proposed by Allen and Meyer.

The explanation above is the basis for making human resource management the main focus in this research, and the theory of organizational behavior as an intermediate theory that covers all aspects of organizational behavior that will be studied, highlighting human behavior as individuals and groups. This research is supported by the application theory (Applied Theory) which is used as a reference in determining the variables involved in this research, namely organizational culture, managerial competence, affective commitment and performance.

\section{Research and Methodology}

\section{Population}

The reasons for choosing the food and beverage industry as the target population for research in Jambi Province are as follows:

i. The food and beverage industry contributed the largest GRDP in Jambi Province from 2015-2019.

ii. The food and beverage industry is a driver of economic activity for the people of Jambi Province.

iii. To support government programs, especially the ministry of industry and trade in small and medium industries.

iv. It is hoped that these research variables can contribute to progress and encourage the development of the food and beverage industry in Jambi Province.

\section{Sample}

This study proposes a probability sampling method with a sample random sampling technique or what is known as simple random sampling. The next stage is to determine the sampling unit, here the sampling unit is the food and beverage industry players, the 
sampling unit is taken from 3 big districts/cities with industry players food and beverage industry is above 800 , and if the three district/city food and beverage industry players are almost 50\% of the total number of food and beverage industry players in Jambi Province, which amount to 5406 (Disperindag Jambi Province, 2019) and can be seen in the following table this :

Table 1: IKM Populations in the Food and Beverage Sector

\begin{tabular}{lll}
\hline No. & County/City & Total Population \\
\hline $\mathbf{1 .}$ & Jambi City & 835 \\
\hline $\mathbf{2 .}$ & Sarolangun & 847 \\
\hline $\mathbf{3 .}$ & Kerinci & 704 \\
\hline Total & & $\mathbf{2 3 8 6}$ \\
\hline
\end{tabular}

Source: Disperindag Prov, 2019

Next is to determine the sample size, Hair, Black, Babin Anderson, (2009), suggest that in the structural equation model (SEM) the sample size plays a major role in the calculation and interpretation of the processed SEM results. According to Loehlin \& Beaujean (2017) to reduce bias in all types of SEM estimates, the number of samples is at least 200. Sampling using probability sampling technique using the slovin formula (Umar, 2010) obtained 343 food and beverage industry players in Jambi Province.

The last stage is selecting the actual sampling units. The total sample of 343 food and beverage industry players will be drawn proportionally in each district/city through the industry and trade office, one of which is to provide guidance and assistance to food and beverage industry players which is carried out periodically.

\section{Data Processing and Analysis Method}

Based on the operational description of the variables above, it can be seen that all data measurements are on an ordinal scale, namely measurements that are arranged sequentially from low to high, then responded in the form of a Differential Semantic scale, which is a scale used to measure respondents' attitudes or perceptions, the form is not multiple choice. or checklist, but arranged in a continuum line where the 'very positive' answer is located on the right side of the line, and the 'very negative' answer is located on the left of the line or vice versa, (Sugiyono, 2016), then the data that has been collected is analyzed in two stages according to with research purposes. The first stage is descriptive analysis and the second stage is path analysis.

\section{Descriptive Analysis}

In this study, descriptive analysis includes a description of the data about the respondent's profile and a description of the data about the research variables. The description of the respondent's profile is made in tabular or graphic format to determine the proportion of each item described. Meanwhile, variable descriptive data is the score perceived by respondents based on a choice of numbers 1 to 10 as in the following example:

Table 2: Scale Range

\begin{tabular}{llllllllllll}
\hline Strongly Disagree & 1 & 2 & 3 & 4 & 5 & 6 & 7 & 8 & 9 & 10 & Strongly agree \\
\hline
\end{tabular}

Table 3: Distribution of Answer Scores

\begin{tabular}{llllll}
\hline Score & Minimum (1) & $\mathbf{2}$ & $\mathbf{3}$ & $\mathbf{4}$ & Maximum (5) \\
\hline Tiers & Very low & Low & Enough & Tall & Very high \\
\hline Score & $20-35.9$ & $36-51.9$ & $52-67.9$ & $68-83.9$ & $84-100$ \\
\hline
\end{tabular}

Source: processed for research, 2021

\section{Data Analysis Tools}

To test the hypothesis, the data analysis tool used in this study is in the form of Structural Equation Modeling (SEM) with a variancebased SEM approach or better known as Partial Least Square (PLS), the software used is smart-PLS. The reason for using PLS in this study is because organizational culture and managerial competence in influencing performance with organizational commitment as a mediator variable in the food and beverage industry in Jambi Province is a predictive study between constructs, where PLS can accommodate formative and reflective constructs. PLS is a soft modeling analysis method that eliminates OLS (Ordinary Least Squares) regression assumptions such as the data must be normally distributed multivariately and there is no multicollinearity problem between exogenous variables and the aim is to test the predictive relationship between constructs by seeing whether there is a relationship or influence between constructs. and research aimed at developing theory using a path approach. PLS will be able to provide analysis in this study organizational culture, and managerial competence is an exogenous variable affecting performance as an endogenous variable with affective commitment as a mediator variable. 


\section{Results And Discussion}

Table 3: Gender of Respondents

\begin{tabular}{llll}
\hline No. & Category & Frequency & Percentage \\
\hline $\mathbf{1}$ & Man & 94 & 27.3 \\
\hline $\mathbf{2}$ & Woman & 252 & 72.7 \\
\hline Total & & 346 & 100 \\
\hline
\end{tabular}

Source: Primary data processing results, 2021

The majority of respondents are female, as many as 252 people or $72.7 \%$. This means that women dominate the food and beverage business group.

Table 4: Age of Respondents

\begin{tabular}{llll}
\hline No. & Category & Frequency & Percentage \\
\hline $\mathbf{1}$ & $<25$ years old & 38 & 11 \\
\hline $\mathbf{2}$ & $25-35$ years old & 69 & 20 \\
\hline $\mathbf{3}$ & $36-45$ years old & 112 & 32 \\
\hline $\mathbf{4}$ & 46-50 years old & 65 & 19 \\
\hline $\mathbf{5}$ & $>50$ years & 62 & 18 \\
\hline Total & & 346 & 100 \\
\hline
\end{tabular}

Source: Primary data processing results, 2021

From table 4, it can be seen that overall, respondents are dominated by those who are in the age range of 36-45 years, which is $32 \%$. In the second place that dominates are those in the $25-55$-year age group reaching $20 \%$. When these two age groups are combined, the amount of dominance reaches $52 \%$. This means that the majority of respondents are of productive age, while for the age category the smallest number is under the age of 25 years by $11 \%$, this means that young people have not started learning to do business from an early age in the food and beverage industry, or at an early age. Some of them are already working in companies/businesses in other fields or taking higher education.

Table 5: Respondents Education Level

\begin{tabular}{llll}
\hline No. & Category & Frequency & Percentage \\
\hline $\mathbf{1}$ & Elementary/junior high school equivalent & 35 & 10 \\
\hline $\mathbf{2}$ & SMA/SMK equivalent & 211 & 61 \\
\hline $\mathbf{3}$ & Diploma & 9 & 2.6 \\
\hline $\mathbf{4}$ & Bachelor degree) & 87 & 25 \\
\hline $\mathbf{5}$ & Master (S2) & 4 & 1.4 \\
\hline Total & & 346 & 100 \\
\hline
\end{tabular}

Source: Primary data processing results, 2021

From table 5 it can be seen that overall respondents are dominated by those with high school/vocational education equivalent, which is $61 \%$, which is as many as 211 people. Then the bachelor graduates in second place by $25 \%$, namely as many as 87 people and the least respondents are master graduates by $1.4 \%$, namely as many as 4 people, business actors

Table 6: Length of Running a Business

\begin{tabular}{llll}
\hline No. & Category & Frequency & Percentage \\
\hline $\mathbf{1}$ & $<$ 1 year & 76 & 22 \\
\hline $\mathbf{2}$ & 23 years & 69 & 20 \\
\hline $\mathbf{3}$ & 4-5 years & 55 & 16 \\
\hline $\mathbf{4}$ & 6 -7 years & 38 & 11 \\
\hline $\mathbf{5}$ & $>$ 8 years & 108 & 31 \\
\hline Total & & 346 & 100 \\
\hline
\end{tabular}

Source: Primary data processing results, 2021

Overall, respondents are dominated by those who have run a business for more than 8 years, which is $31 \%$. This means that business actors are experienced enough in the food and beverage industry. The next order is dominated by business actors who have just started a business/new entrant whose business has not been in business for less than a year, which is $22 \%$, this phenomenon can be caused because the food and beverage industry is popping up everywhere in accordance with government support in creating new entrepreneurs in the field of food and beverage. culinary. 
Table 7: Respondents' Income Level

\begin{tabular}{llll}
\hline No. & Category & Frequency & Percentage \\
\hline $\mathbf{1}$ & < Rp.500.000-Rp.1.000.000 & 84 & 24.3 \\
\hline $\mathbf{2}$ & IDR 1,000,000 - IDR 2,000,000 & 86 & 25 \\
\hline $\mathbf{3}$ & IDR 3,000,000 - IDR 4,000,000 & 46 & 13.2 \\
\hline $\mathbf{4}$ & IDR 5,000,000 - IDR 10,000,000 & 72 & 20.8 \\
\hline $\mathbf{5}$ & $>$ Rp.10,000,000 & 58 & 16.7 \\
\hline Total & & 346 & 100 \\
\hline
\end{tabular}

Source: Primary data processing results, 2021

Overall, respondents are dominated by those who have an income range between 500 thousand rupiah to one million rupiah, which is $24.3 \%$ and those who have an income range from more than one million rupiah to two million rupiah, which is $25 \%$. mostly obtained by business actors. In addition to the two categories above, income ranging from five million to 10 million also gets a large portion, which is $20.8 \%$, this is made possible by business actors who are already mature and have experience in running a business in the food and beverage industry in Jambi Province.

Table 8: Sources of Business Capital

\begin{tabular}{llll}
\hline No. & Category & Frequency & Percentage \\
\hline $\mathbf{1}$ & Fully own capital & 214 & 62 \\
\hline $\mathbf{2}$ & Borrow from the bank & 14 & 4 \\
\hline $\mathbf{3}$ & Borrow not from the bank & 3 & 1 \\
\hline $\mathbf{4}$ & Own capital and borrow from the bank & 73 & 21 \\
\hline $\mathbf{5}$ & Own capital and borrow not from the bank & 42 & 12 \\
\hline Total & & 346 & 100 \\
\hline
\end{tabular}

Source: Primary data processing results, 2021

Food and beverage business actors in running their business use their own capital fully, which is $62 \%$, then business actors in addition to fully using their own capital also use bank loans, which are $21 \%$, the government does provide small business loans (KIK) with low interest. The category of source of business capital that has the smallest percentage is $100 \%$ borrowing from a bank by $1 \%$, this is due to business actors who do not want to take high risks in starting a food and beverage business.

Variable Description

Table 9: Description of Organizational Culture

\begin{tabular}{lllllll}
\hline No. & Dimension & $\begin{array}{l}\text { Ideal } \\
\text { Score }\end{array}$ & $\begin{array}{l}\text { Actual } \\
\text { Score }\end{array}$ & Index $(\%)$ & Score Range & Category \\
\hline $\mathbf{1}$ & Dominant Characteristics & 6920 & 5723 & $82 \%$ & $68-83.9$ & High \\
\hline $\mathbf{2}$ & Organizational Leadership & 6920 & 5740 & $82 \%$ & $68-83.9$ & High \\
\hline $\mathbf{3}$ & Personnel management & 6920 & 5678 & $82 \%$ & $68-83.9$ & High \\
\hline $\mathbf{4}$ & Organizational adhesive & 6920 & 5916 & $85 \%$ & $84-100$ & Very high \\
\hline $\mathbf{5}$ & Strategy Emphasis & 6920 & 5824 & $84 \%$ & $84-100$ & Very high \\
\hline $\mathbf{6}$ & Success Criteria & 6920 & 5792 & $83 \%$ & $68-83.9$ & High \\
\hline
\end{tabular}

Source: Primary data processing results, 2021

As shown in this table, the average level of respondent agreement (TKR) on organizational culture in the food and beverage industry in Jambi Province is $83 \%$, which means that it is in the high category and seen from the scale range in this category, namely 68-83 ,9, this respondent's assessment can be said to be very high because in the range of this scale the number 85 is in the highest position.

Table illustrates that for the dominant characteristic dimensions: organizational leadership, personnel management, success criteria get a high category, this means that the organizational culture of food and beverage business actors is market-type, which is resultsoriented, work achievement and competitive performance, then very high category means culture The clan character formed is characterized by loyalty, mutual trust, teamwork, participation from employees, the high and very high categories indicate that the organizational culture has been practiced well. 
Table 10: Description of Managerial Competencies

\begin{tabular}{|c|c|c|c|c|c|c|}
\hline No. & Dimension & $\begin{array}{l}\text { Ideal } \\
\text { Score }\end{array}$ & $\begin{array}{l}\text { Actual } \\
\text { Score }\end{array}$ & Index $(\%)$ & Score Range & Category \\
\hline 1 & Managing Team & 3460 & 2925 & $84 \%$ & $84-100$ & Very high \\
\hline 2 & $\begin{array}{l}\text { Managing Relationships Between } \\
\text { Individuals }\end{array}$ & 3460 & 2861 & $82 \%$ & $68-83.9$ & High \\
\hline 3 & Managing Employee Development & 3460 & 2859 & $82 \%$ & $68-83.9$ & High \\
\hline 4 & Managing Innovation & 3460 & 2835 & $81 \%$ & $68-83.9$ & High \\
\hline 5 & Managing the Future & 3460 & 2874 & $83 \%$ & $68-83.9$ & High \\
\hline 6 & Managing Continuous Improvement & 3460 & 2922 & $84 \%$ & $84-100$ & Very high \\
\hline 7 & Managing Competition & 3460 & 2871 & $82 \%$ & $68-83.9$ & High \\
\hline 8 & Encouraging Employees & 3460 & 2934 & $84 \%$ & $84-100$ & Very high \\
\hline 9 & Managing Customer Service & 3460 & 2819 & $81 \%$ & $68-83.9$ & High \\
\hline 10 & Managing Cultural Acculturation & 3460 & 2868 & $82 \%$ & $68-83.9$ & High \\
\hline 11 & Manage Control System & 3460 & 2863 & $82 \%$ & $68-83.9$ & High \\
\hline 12 & Managing Coordination & 3460 & 2842 & $82 \%$ & $68-83.9$ & High \\
\hline
\end{tabular}

Source: Primary data processing results, 2021

As shown in table, the average level of respondent agreement (TKR) on managerial competence in the food and beverage industry is only $82.4 \%$, which means it is in the high category and can be seen from the scale range in this category, namely 68 - 83.9 this respondent's rating can be said to be high because in this scale range the number 84 is in a high position.

For managerial competence with a high category, it means that business actors apply ways of communicating, guiding, improving self-management abilities, encouraging ideas, new work methods and monitoring performance directly. For the very high category, it means that food and beverage business actors build team cohesiveness with full commitment and improve processes in order to achieve the desired results, in addition, high and very high categories indicate that managerial competence has been practiced very well by business actors.

Table 11: Description of Affective Commitment

\begin{tabular}{lllllll}
\hline No. & Dimension & $\begin{array}{l}\text { Ideal } \\
\text { Score }\end{array}$ & $\begin{array}{l}\text { Actual } \\
\text { Score }\end{array}$ & Index (\%) & Score Range & Category \\
\hline $\mathbf{1}$ & Personal Characteristics & 6920 & 5934 & $85 \%$ & $84-100$ & Very high \\
\hline $\mathbf{2}$ & Structural Characteristics & 6920 & 6005 & $86 \%$ & $84-100$ & Very high \\
\hline $\mathbf{3}$ & Related Job Characteristics & 6920 & 5790 & $83 \%$ & $68-83.9$ & High \\
\hline $\mathbf{4}$ & Work experience & 6920 & 5754 & $83 \%$ & $68-83.9$ & High \\
\hline
\end{tabular}

Source: Results of primary data processing, 2021

As shown in this table, the average level of respondent agreement (TKR) on affective commitment to the food and beverage industry in Jambi Province is $84.2 \%$, which means that it is in the very high category. This is $84-100$, this respondent's assessment can be said to be high because in this scale range the number 86 is in the highest position. The dimensions of work characteristics and work experience get a high category, this means that food and beverage business actors feel happy with their work and are ready to give all their abilities to their work and feel that business problems are also considered to be personal problems, then the dimensions of personal characteristics and structural characteristics get a very high category. high, this means that business actors feel the company is very meaningful and feel there is an emotional bond to the company, the high and very high categories indicate that affective commitment has been practiced well.

Table 12: Performance Description

\begin{tabular}{lllllll}
\hline No. & Dimension & $\begin{array}{l}\text { Ideal } \\
\text { Score }\end{array}$ & $\begin{array}{l}\text { Actual } \\
\text { Score }\end{array}$ & Index (\%) & Score Range & Category \\
\hline $\mathbf{1}$ & Quality & 6920 & 6069 & $87 \%$ & $84-100$ & Very high \\
\hline $\mathbf{2}$ & Time & 6920 & 6022 & $87 \%$ & $84-100$ & Very high \\
\hline $\mathbf{3}$ & Flexibility & 6920 & 5861 & $84 \%$ & $84-100$ & Very high \\
\hline $\mathbf{4}$ & Finance & 6920 & 5781 & $83 \%$ & $68-83.9$ & High \\
\hline $\mathbf{5}$ & Customer satisfaction & 6920 & 6177 & $89 \%$ & $84-100$ & Very high \\
\hline $\mathbf{6}$ & Human Resources & 6920 & 5952 & $86 \%$ & $84-100$ & Very high \\
\hline
\end{tabular}

Source: Primary data processing results, 2021 
The respondent's level of agreement (TKR) on performance in the food and beverage industry in Jambi Province is on average $86 \%$, which means it is in the very high category. This figure shows that the performance of food and beverage industry players has been practiced well, and judging from the scale range in this category, namely 84-100, this respondent's assessment can be said to be still low because in this scale range the number 89 is in the highest position.

Dimensions that get a very high category are quality, time, flexibility, customer satisfaction and human resources, this means that business actors innovate, develop, and sell good quality products, products are made according to the right process and time, the business carried out also has loyal customers and provide the best service. The financial dimension is in the high category, this means that food and beverage business actors receive appropriate income even though the income has decreased due to the COVID-19 pandemic, for this reason, business actors reduce unnecessary costs both from production and marketing volumes.

\section{Statistical Test Result}

Outer Model Measurement

\section{Validity Test}

\section{Convergent validity}

\section{Loading Factor}

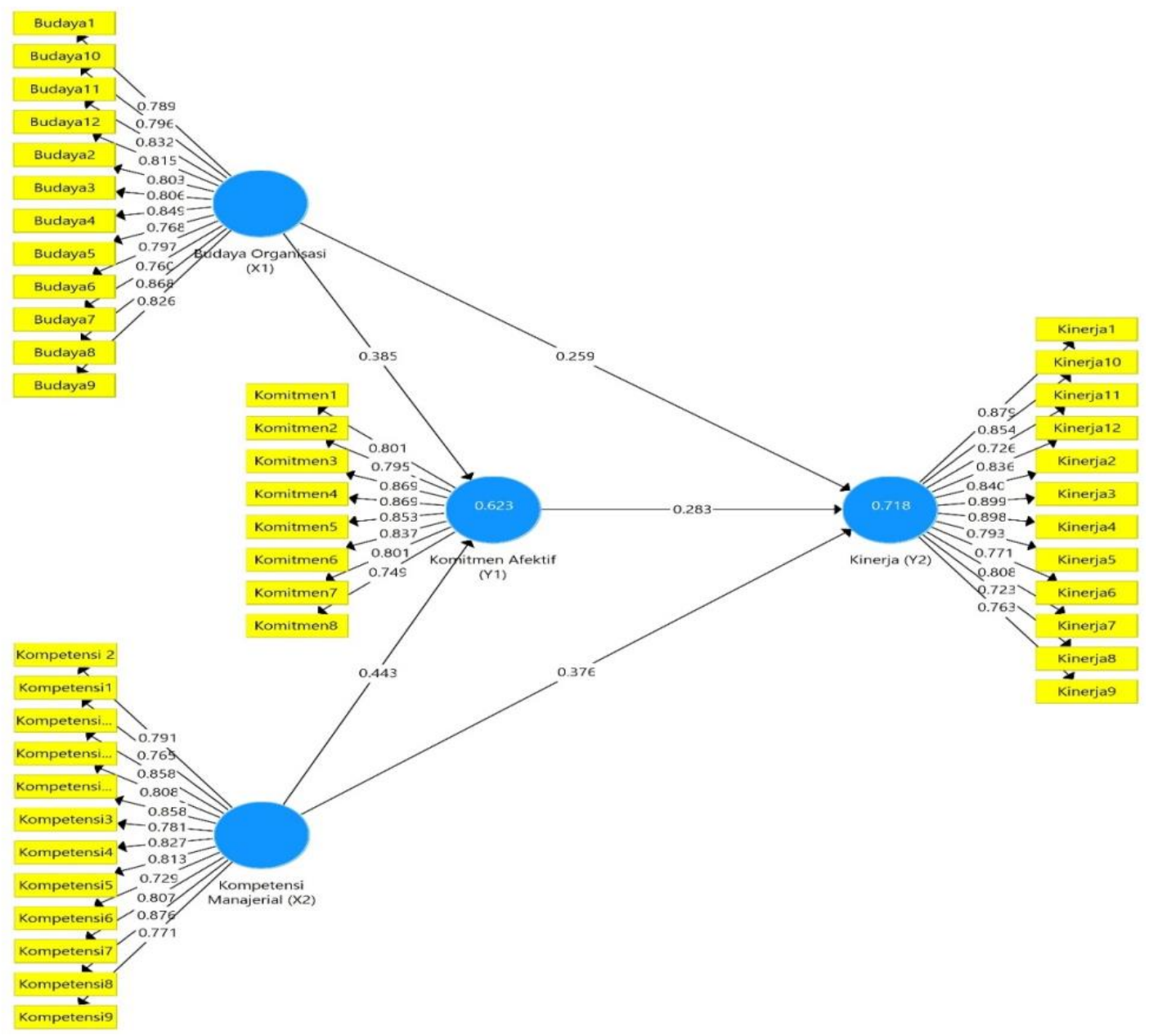

Figure 1: PLS Structural Model; Source: Output SmartPLS version 3.3.3 (2021) 
Table 13: Outer Loading Value (loading factor)

\begin{tabular}{|c|c|c|c|c|c|c|c|}
\hline \multicolumn{2}{|c|}{$\begin{array}{l}\text { Organizational } \\
\text { culture }\end{array}$} & \multicolumn{2}{|c|}{ Managerial Competence } & \multicolumn{2}{|c|}{ Affective Commitment } & \multicolumn{2}{|l|}{ Performance } \\
\hline Culture1 & 0.789 & Competency 2 & 0.791 & Commitment1 & 0.801 & Performance1 & 0.879 \\
\hline Culture10 & 0.796 & Competence1 & 0.765 & Commitment2 & 0.795 & Performance10 & 0.854 \\
\hline Culture11 & 0.832 & Competency 10 & 0.858 & Commitment3 & 0.869 & Performance11 & 0.726 \\
\hline Culture12 & 0.815 & Competency11 & 0.808 & Commitment 4 & 0.869 & Performance12 & 0.836 \\
\hline Culture2 & 0.803 & Competency12 & 0.858 & Commitment5 & 0.853 & Performance2 & 0.840 \\
\hline Culture3 & 0.806 & Competence3 & 0.781 & Commitment6 & 0.837 & Performance 3 & 0.899 \\
\hline Culture4 & 0.849 & Competency4 & 0.827 & Commitment7 & 0.801 & Performance4 & 0.898 \\
\hline Culture5 & 0.768 & Competence5 & 0.813 & Commitment8 & 0.749 & Performance 5 & 0.793 \\
\hline Culture6 & 0.797 & Competency6 & 0.729 & & & Performance6 & 0.771 \\
\hline Culture7 & 0.760 & Competency 7 & 0.807 & & & Performance7 & 0.808 \\
\hline Culture8 & 0.868 & Competency 8 & 0.876 & & & Performance8 & 0.723 \\
\hline Culture9 & 0.826 & Competency9 & 0.771 & & & Performance9 & 0.763 \\
\hline
\end{tabular}

Source: Primary Data Processing Results, 2021

From Table it can be concluded several things as follows: (1) All items that reflect organizational culture have a loading factor value $>0.7$. Thus, the research instrument used to measure organizational culture is valid, (2) All items that reflect managerial competence have a loading factor value of $>0.7$. Thus, the research instrument used to measure managerial competence is valid. (3) All items that reflect affective commitment have a loading factor value of $>0.7$. Thus, the research instrument used to measure affective commitment is valid, and (4) All items that reflect performance have a loading factor value of $>0.7$. Thus, the research instrument used to measure performance is valid.

Average Variance Extracted (AVE)

Table 14: Average Variance Extracted (AVE) Value

\begin{tabular}{ll}
\hline & Average Variance Extracted (AVE) \\
\hline Organizational Culture (X1) & 0.656 \\
\hline Performance (Y2) & 0.669 \\
\hline Affective Commitment (Y1) & 0.677 \\
\hline Managerial Competence (X2) & 0.653 \\
\hline Source: SmartPLS 3.3.3 Output Data Processed (2021)
\end{tabular}

Source: SmartPLS 3.3.3 Output Data Processed (2021)

The average extract variance (AVE) with a value $>0.5$ was used as a determinant of convergent validity. So if AVE $<0.5$ then it is not convergently valid. So that the expected AVE value is greater than 0.5. Based on Table the AVE value above, it is known that the AVE value of the Organizational Culture variable (X1) is $0.656>0.5$; the AVE value of the Performance variable (Y2) is 0.669 $>0.5$; the AVE value of the Affective Commitment variable (Y1) is $0.677>0.5$; and the AVE value of Managerial Competence (X2) is $0.653>0.5$. That is, the research instrument used to measure Organizational Culture, Managerial Competence, Affective Commitment, and Performance is valid.

Discriminant Validity

Fornell Larcker

Table 15: Fornell-Larcker Criteria

\begin{tabular}{lllll}
\hline & $\begin{array}{l}\text { Organizational } \\
\text { Culture (X1) }\end{array}$ & Performance (Y2) & $\begin{array}{l}\text { Affective } \\
\text { Commitment (Y1) }\end{array}$ & $\begin{array}{l}\text { Managerial } \\
\text { Competence (X2) }\end{array}$ \\
\hline Organizational Culture (X1) & $\mathbf{0 . 8 1 0}$ & 0.259 & 0.385 & \\
\hline Performance (Y2) & & $\mathbf{0 . 8 1 8}$ & & \\
\hline Affective Commitment (Y1) & & 0.283 & $\mathbf{0 . 8 2 3}$ & $\mathbf{0 . 8 0 8}$ \\
\hline Managerial Competence (X2) & & 0.376 & 0.443 & \\
\hline
\end{tabular}

Source: SmartPLS 3.3.3 Output Data Processed (2021)

Based on Table above, it can be seen that the square root value of the AVE (Fornell-Lacker value) Organizational Culture (X1) is 0.810, which is greater than the correlation value of Organizational Culture with Affective Commitment which is 0.385 and the correlation value of Organizational Culture with Performance is 0.259 . The square root value of the AVE (Fornell-Lacker value) Managerial Competence (X2) is 0.808, which is greater than the correlation value between Managerial Competence and Affective Commitment which is 0.443 and the correlation value of Managerial Competence with Performance is 0.376 . The square root value of the AVE (Fornell-Lacker value) of Affective Commitment (Y1) is 0.823, which is greater than the correlation value of Affective 
Commitment with Performance which is 0.283 . This shows that at the construct level, discriminantly, the indicators used to measure Organizational Culture, Managerial Competence, Affective Commitment, and Performance, are valid.

Cross Loading

Table 16: Cross Loading Value

\begin{tabular}{|c|c|c|c|c|c|}
\hline Indicator/ Variable & $\begin{array}{l}\text { Organizational } \\
\text { Culture (X1) }\end{array}$ & Performance (Y2) & $\begin{array}{l}\text { Affective } \\
\text { Commitment (Y1) }\end{array}$ & $\begin{array}{l}\text { Managerial } \\
\text { (X2) }\end{array}$ & Competence \\
\hline Culture1 & 0.789 & 0.565 & 0.578 & 0.704 & \\
\hline Culture10 & 0.796 & 0.604 & 0.516 & 0.580 & \\
\hline Culture11 & 0.832 & 0.582 & 0.534 & 0.607 & \\
\hline Culture12 & 0.815 & 0.644 & 0.650 & 0.651 & \\
\hline Culture2 & 0.803 & 0.595 & 0.605 & 0.649 & \\
\hline Culture3 & 0.806 & 0.592 & 0.594 & 0.605 & \\
\hline Culture4 & 0.849 & 0.674 & 0.662 & 0.709 & \\
\hline Culture5 & 0.768 & 0.608 & 0.587 & 0.625 & \\
\hline Culture6 & 0.797 & 0.603 & 0.582 & 0.669 & \\
\hline Culture7 & 0.760 & 0.694 & 0.681 & 0.710 & \\
\hline Culture8 & 0.868 & 0.722 & 0.671 & 0.747 & \\
\hline Culture9 & 0.826 & 0.626 & 0.550 & 0.638 & \\
\hline Performance1 & 0.729 & 0.879 & 0.644 & 0.717 & \\
\hline Performance10 & 0.623 & 0.854 & 0.621 & 0.667 & \\
\hline Performance11 & 0.523 & 0.726 & 0.478 & 0.546 & \\
\hline Performance12 & 0.664 & 0.836 & 0.583 & 0.657 & \\
\hline Performance2 & 0.658 & 0.840 & 0.652 & 0.685 & \\
\hline Performance3 & 0.669 & 0.899 & 0.683 & 0.687 & \\
\hline Performance4 & 0.662 & 0.898 & 0.639 & 0.707 & \\
\hline Performance5 & 0.579 & 0.793 & 0.588 & 0.634 & \\
\hline Performance6 & 0.628 & 0.771 & 0.678 & 0.651 & \\
\hline Performance7 & 0.631 & 0.808 & 0.632 & 0.637 & \\
\hline Performance8 & 0.665 & 0.723 & 0.676 & 0.604 & \\
\hline Performance9 & 0.557 & 0.763 & 0.560 & 0.648 & \\
\hline Commitment1 & 0.632 & 0.577 & 0.801 & 0.634 & \\
\hline Commitment2 & 0.536 & 0.584 & 0.795 & 0.546 & \\
\hline Commitment3 & 0.651 & 0.651 & 0.869 & 0.660 & \\
\hline Commitment4 & 0.607 & 0.663 & 0.869 & 0.678 & \\
\hline Commitment5 & 0.618 & 0.601 & 0.853 & 0.613 & \\
\hline Commitment6 & 0.617 & 0.680 & 0.837 & 0.645 & \\
\hline Commitment7 & 0.641 & 0.659 & 0.801 & 0.617 & \\
\hline Commitment8 & 0.605 & 0.582 & 0.749 & 0.579 & \\
\hline Competency 2 & 0.589 & 0.596 & 0.535 & 0.791 & \\
\hline Competence1 & 0.718 & 0.650 & 0.568 & 0.765 & \\
\hline Competency10 & 0.700 & 0.728 & 0.714 & 0.858 & \\
\hline Competency11 & 0.656 & 0.685 & 0.660 & 0.808 & \\
\hline Competency12 & 0.715 & 0.692 & 0.742 & 0.858 & \\
\hline Competence3 & 0.656 & 0.567 & 0.584 & 0.781 & \\
\hline Competency4 & 0.668 & 0.635 & 0.577 & 0.827 & \\
\hline Competence5 & 0.643 & 0.676 & 0.571 & 0.813 & \\
\hline Competency6 & 0.605 & 0.532 & 0.515 & 0.729 & \\
\hline Competency7 & 0.676 & 0.629 & 0.585 & 0.807 & \\
\hline Competency8 & 0.702 & 0.731 & 0.653 & 0.876 & \\
\hline Competency9 & 0.570 & 0.607 & 0.588 & 0.771 & \\
\hline
\end{tabular}

Source: Data output SmartPLS 3.3.3 Processed (2021)

Based on Table the value of Cross Loading, it is known that all cross-loading values of the Organizational Culture indicator to the intended construct (Organizational Culture) are higher than the cross-loading value of other constructs. Likewise, all the crossloading values of Managerial Competence indicators for the intended construct (Managerial Competence) are higher than the crossloading values for other constructs. All cross-loading values of Affective Commitment indicators to the intended construct 
(Affective Commitment) are higher than the cross-loading values of other constructs. All crossloading values of performance indicators towards the intended construct (Performance) are higher than the cross-loading values of other constructs.

\section{Reliability Test}

Table 17: Cronbach's Alpha and Composite Reliability Values

\begin{tabular}{lll}
\hline Variable & $\begin{array}{l}\text { Cronbach's } \\
\text { Alpha }\end{array}$ & $\begin{array}{l}\text { Composite } \\
\text { Reliability }\end{array}$ \\
\hline Organizational Culture (X1) & 0.952 & 0.958 \\
\hline Performance (Y2) & 0.954 & 0,960 \\
\hline Affective Commitment (Y1) & 0.931 & 0.944 \\
\hline Managerial Competence (X2) & 0.951 & 0.957 \\
\hline
\end{tabular}

Source: SmartPLS 3.3.3 Output Data Processed (2021)

Reliability or reliability of research instruments for reflective indicators can be tested through Cronbach's Alpha and Composite Reliability values. The instrument is said to be reliable if the value of Cronbach's alpha $>0.6$ and the value of composite reliability $>0.8$. Based on Table above, it is known that the value of Cronbach's alpha of the Organizational Culture variable is $0.952>$ 0.6; Performance of $0.954>0.6$; Affective Commitment is 0.931; and Managerial Competence of 0.951 > 0.6. This shows that the research instrument used to measure Organizational Culture, Performance, Affective Commitment, and Managerial Competence is considered reliable. Likewise with the composite reliability value, based on the table above, it is known that the composite reliability value of the Organizational Culture variable is $0.958>0.8$; Performance of $0.960>0.8$; Affective Commitment is 0.944 $>0.8$; and Managerial Competence of $0.957>0.8$. These results strengthen the test results through the value of Cronbach's alpha which shows that the outer model for the reflective indicators of the variables of Organizational Culture, Performance, Affective Commitment, and Managerial Competence is Reliable.

\section{Inner Model (Structural Model)}

Tests on the structural model were conducted to test the relationship between latent constructs. There are several tests for the structural model, namely: R-Square $\left(\mathrm{R}^{2}\right.$ ), Effect Size (f Square), $\mathrm{Q}^{2}$, and GoF. The following is a more detailed analysis of each inner model test.

\section{R Square $\left(\mathbf{R}^{2}\right)$}

The value of R Square is the coefficient of determination on the endogenous construct. According to Chin (1998), the value of R square is 0.67 (strong), 0.33 (moderate) and 0.19 (weak).

Table 18: R-Square Value

\begin{tabular}{lc}
\hline Variable & R Square \\
\hline Affective Commitment (Y1) & 0.623 \\
\hline Performance (Y2) & 0.718 \\
\hline
\end{tabular}

Source: SmartPLS 3.3.3 Output Data Processed, 2021

\section{Effect Size ( $\left.\mathbf{f}^{2}\right)$}

In addition to examining the R-Square, an examination was also carried out regarding the effect of endogenous variables on known exogenous variables based on the value of effect size $\left(f^{2}\right)$ which is presented in the following table.

Table 19: Effect Size Value (f2)

\begin{tabular}{lll}
\hline & Performance (Y2) & Affective Commitment (Y1) \\
\hline Organizational Culture (X1) & 0.070 & 0.132 \\
\hline Affective Commitment (Y1) & 0.107 & \\
\hline Managerial Competence (X2) & 0.142 & 0.174
\end{tabular}

Source: SmartPLS 3.3.3 Output Data Processed, 2021

\section{Q Square $\left(\mathbf{Q}^{2}\right)$}

Here's Inner testing model can be done by looking at the value of $\mathrm{Q}^{2}$ ( predictive relevance). To calculate $\mathrm{Q}^{2}$ can use the formula: 
$\mathrm{Q}^{2}=1-\left(1-\mathrm{R}_{1}^{2}\right)\left(1-\mathrm{R}_{2}^{2}\right) \ldots . .\left(1-\mathrm{R}_{\mathrm{p}}^{2}\right)$

$\mathrm{Q}^{2}=1-(1-0.623)(1-0.718)=1-0.106314=0.893686$

As $\mathrm{R}^{2}$, it also shows that about $89 \%$ of Performance is explained by Organizational Culture, Managerial Competence, and Affective Commitment.

\section{Goodness of Fit (GoF)}

The last part of the inner model test is to find the Goodness of Fit (GoF) value. In contrast to CB-SEM, the GoF value in SEM-PLS must be calculated manually. In accordance with the formula from Tenenhaus (2004), namely GoF $=. \sqrt{A V E \times R^{2}}$.

For $\mathrm{R}^{2}=0.623$ we get:

GoF Organizational Culture $=\sqrt{0,656 \times 0,623}=0,639$

GoF Managerial Competence $=\sqrt{0,653 \times 0,623}=0,638$

For $\mathrm{R}^{2}=0.718$, we get:

GoF Organizational Culture $=\sqrt{0,656 \times 0,718}=0,686$

GoF Managerial Competence $=\sqrt{0,653 \times 0,718}=0,685$

GoF Affective Commitment $=\sqrt{0,677 \times 0,718}=0,697$

According to Tenenhaus (2004), small GoF $=0.1$, medium $\mathrm{GoF}=0.25$ and large $\mathrm{GoF}=0.38$. Based on the calculation results above, it shows that the GoF value of each latent construct is greater than 0.38 , which means that the structural model formed meets the goodness of fit or the structural model that is formed is good, fits the field conditions, and can be used to predict organizational performance. So that the structural model can be accepted .

From the test of $\mathrm{R}^{2}, \mathrm{f}^{2}, \mathrm{Q}^{2}$ and $\mathrm{GoF}$, it can be seen that the structural model formed is robust . So that hypothesis testing can be done.

Hypothesis test

Table 20: Estimated Path Coefficients and T-Statistics Total Effect

\begin{tabular}{llll}
\hline Relationship Between Variables & $\begin{array}{l}\text { Original } \\
\text { Sample } \\
(\mathbf{O})\end{array}$ & $\begin{array}{l}\text { T } \\
(|\mathbf{O} / \mathbf{S T D E V}|)\end{array}$ & \multicolumn{1}{c}{ Statistics Values } \\
\hline Direct Influence & & & 0.000 \\
\hline Cultural Organizations (X1) -> Performance (Y2) & 0.259 & 3.574 & 0.000 \\
\hline Organizational Culture (X1) -> Affective Commitment (Y1) & 0.385 & 5,397 & 0.000 \\
\hline Affective Commitment (Y1) -> Performance (Y2) & 0.283 & 3,909 & 0.000 \\
\hline Managerial Competence (X2) -> Performance (Y2) & 0.376 & 4,364 & 0.000 \\
\hline Managerial Competence (X2) -> Affective Commitment (Y1) & 0.443 & 6,024 & \\
\hline
\end{tabular}

Source: SmartPLS 3.3.3 Output Data Processed (2021)

Based on the Original Sample O values in Table for the Direct Effect above, as well as in Figure of the previous Structural Model, the main structural equations formed are:

Model 1: $Y_{1}=0,385 X_{1}+0,443 X_{2}+\varepsilon$

Model 2: $Y_{2}=0,259 X_{1}+0,376 X_{2}+0,283 Y_{1}+\varepsilon$

where Y1 is Affective Commitment, Y2 is Performance, X1 is Organizational Culture, X2 is Managerial Competence. As for the error or error factor in each model.

\section{First Hypothesis Testing ( $\left.\mathrm{H}_{1}\right)$}

Meanwhile, based on the structural equation Model 2 that was formed, it is known that the coefficient of the main path structural model (original sample O) Organizational Culture towards Performance has a positive value of 0.259 units. This shows that organizational culture has a positive effect on performance, where the higher the organizational culture, the higher the performance. The increase in each unit of Organizational Culture will increase performance by 0.259 units. The t-statistics coefficient of the main path structural model (original sample O) Organizational Culture on Performance is $3.574>1.96$ (normal Z-score value for $=0.05)$ and P-value of $0.000<0.05$. This shows that Organizational Culture has a positive and significant effect on Performance. So that the first hypothesis of the study which states that "Organizational Culture has a positive and significant influence on Performance", is accepted. The findings in this study explain that clan- type organizational culture affects performance this is due to a strong culture of togetherness and kinship in an organization if implemented consistently so that it will improve organizational performance. The formation of good performance is produced if there is communication between all business owners 
and employees so as to form a strong internalization of organizational culture that is understood in accordance with organizational values that can lead to positive perceptions among all employees to support and influence performance. This research is supported by research by Gunaraja (2014) and Haryanti (2014) which state that organizational culture has a positive contribution to employee performance, in addition to research conducted by Adi (2013) which examines the influence of organizational culture on performance, where the results show that organizational culture has an effect on positive on performance.

\section{Second Hypothesis Testing ( $\left.\mathrm{H}_{2}\right)$}

Based on the structural equation Model 2 formed, it is known that the coefficient of the main path structural model (original sample O) Managerial Competence towards Performance has a positive value of 0.376 units. This shows that managerial competence has a positive effect on performance, where the higher the managerial competence, the higher the performance. The increase in each unit of Managerial Competence will increase performance by 0.376 units. The t-statistics value of the main line structural model coefficient (original sample O) Managerial Competence on Performance is $4.364>1.96$ (normal Z-score value for $=0.05$ ) and $\mathrm{P}$ value of $0.000<0.05$. This shows that managerial competence has a positive and significant effect on performance. In such a way that the second hypothesis of the study which states that "managerial competence has a positive and significant influence on performance", is accepted. The findings in this study that managerial competence has a positive effect on performance, where the higher the managerial competence, the higher the performance, this is due to the importance of leadership in carrying out business activities, in addition Anand Bhardwaj (2013) also obtained research results in the International Journal of Advanced Research studies the relationship between managerial competence and performance. The results state that team work, pro-activity, vision, selfmanagement, communication skills, results and strategic orientation, risk-taking, decision-making and creativity are some of the factors that must be possessed by leaders in organizing so that they can advance an organization that produces good performance. optimal.

\section{Third Hypothesis Testing ( $\mathrm{H}_{3}$ )}

Based on the structural equation Model 1 formed, it is known that the coefficient of the main path structural model (original sample O) Organizational Culture towards Affective Commitment has a positive value of 0.385 units. This shows that Organizational Culture has a positive effect on Affective Commitment, where the higher the Organizational Culture, the higher the Affective Commitment. The increase in each unit of Organizational Culture will increase Affective Commitment by 0.385 units. The t-statistics value of the coefficient of the main path structural model (original sample O) Organizational Culture on Affective Commitment is $5.397>1.96$ (normal Z-score value for $=0.05$ ) and $\mathrm{P}$-value of $0.000<0.05$. This shows that Organizational Culture has a positive and significant effect on Affective Commitment. So that the third hypothesis of the study which states that " Organizational culture has a positive and significant influence on Affective Commitment", is accepted. The findings in this study are organizational culture has a positive and significant influence on affective commitment. The relationship between organizational culture and organizational commitment was also revealed in the research of Hsi-Chi, Jen-Chia, Ya-Ling, (2012) showing a positive relationship. Likewise, research conducted by Ali Shurbagi \& Zahari (2014) confirmed a positive and significant relationship between organizational culture and organizational commitment. Organizational culture has a close relationship with organizational commitment, it is based that organizational culture facilitates shared commitment. Where through organizational culture also serves to share norms, values and perceptions of the organization in order to form a common goal.

\section{Fourth Hypothesis Testing ( $\mathrm{H}_{4}$ )}

Based on the structural equation Model 1 formed, it is known that the coefficient of the main path structural model (original sample O) managerial competence towards affective commitment has a positive value of 0.443 units. This shows that Managerial Competence has a positive effect on Affective Commitment, where the higher the Managerial Competence, the higher the Affective Commitment. The increase in each unit of Managerial Competence will increase Affective Commitment by 0.443 units. The $\mathrm{t}-$ statistics value of the coefficient of the main line structural model (original sample O) Managerial Competence on Affective Commitment is $6.024>1.96$ (normal Z-score value for $=0.05$ ) and P-value of $0.000<0.05$. This shows that Managerial Competence has a positive and significant effect on Affective Commitment. So that the fourth hypothesis of the study which states that "Managerial Competence has a positive and significant influence on Affective Commitment", is accepted.

The findings in this study indicate that Managerial Competence has a positive effect on Affective Commitment, where the higher the Managerial Competence, the higher the Affective Commitment, this finding is in line with research conducted by Basilius Redan Werang (2018) on principals in Boven Digoel district, Papua The results of data analysis show that the principal's managerial skills and school climate have a positive and significant effect on teacher work commitment, according to (Yukl, 2006) First, conceptual skills or conceptual skills. Conceptual skills consist of analytical abilities, rational thinking, forming concepts, inductive and deductive thinking. In general, conceptual skills can be seen in the ability to provide good judgment, can see into the future, creativity, intuition, and the ability to find meaning and order in the uncertainty of events and ambiguity. Second, human-relation skills or human relations skills. Human relations skills consist of knowledge of human behavior and group processes, the ability to understand the feelings, attitudes and motivations of others. Third, technical skills or technical skills. Technical skills lead to knowledge of the methods, processes, and equipment to perform certain actions. 


\section{Fifth Hypothesis Testing ( $\left.\mathrm{H}_{5}\right)$}

Based on the structural equation Model 2, it is also known that the coefficient of the main path structural model (original sample O) Affective Commitment to Performance has a positive value of 0.283 units. This shows that Affective Commitment has a positive effect on Performance, where the higher the Affective Commitment, the higher the Performance. The increase in each unit of Affective Commitment will increase Performance by 0.283 units.

Table 21: Estimation of Path Coefficients and T-statistics Outer Loading

\begin{tabular}{|c|c|c|c|}
\hline Indicators / Variables & $\begin{array}{l}\text { Original } \\
\text { Sample (O) }\end{array}$ & $\begin{array}{l}\text { T } \quad \text { Statistics } \\
(\mid \text { O/STDEV } \mid)\end{array}$ & P Values \\
\hline Culture1 <- Organizational Culture (X1) & 0.789 & 25,184 & 0.000 \\
\hline Culture $10<-$ Organizational Culture (X1) & 0.796 & 23,248 & 0.000 \\
\hline Culture $11<-$ Organizational Culture (X1) & 0.832 & 33,232 & 0.000 \\
\hline Culture $12<-$ Organizational Culture (X1) & 0.815 & 34,188 & 0.000 \\
\hline Culture2 <- Organizational Culture (X1) & 0.803 & 28,832 & 0.000 \\
\hline Culture3 <- Organizational Culture (X1) & 0.806 & 23,545 & 0.000 \\
\hline Culture4 <- Organizational Culture (X1) & 0.849 & 49,562 & 0.000 \\
\hline Culture5 <- Organizational Culture (X1) & 0.768 & 24,654 & 0.000 \\
\hline Culture6 <- Organizational Culture (X1) & 0.797 & 21,274 & 0.000 \\
\hline Budaya7 <- Cultural Organization (X1) & 0.760 & 27,811 & 0.000 \\
\hline Culture8 <- Organizational Culture (X1) & 0.868 & 47,610 & 0.000 \\
\hline Culture9 <- Organizational Culture (X1) & 0.826 & 32,380 & 0.000 \\
\hline Performance1 <- Performance (Y2) & 0.879 & 54,377 & 0.000 \\
\hline Performance $10<-$ Performance (Y2) & 0.854 & 47,491 & 0.000 \\
\hline Performance $11<-$ Performance (Y2) & 0.726 & 14,463 & 0.000 \\
\hline Performance 12 <- Performance (Y2) & 0.836 & 42,859 & 0.000 \\
\hline Performance $2<-$ Performance (Y2) & 0.840 & 48,664 & 0.000 \\
\hline Performance3 <- Performance (Y2) & 0.899 & 71,970 & 0.000 \\
\hline Performance $4<-$ Performance (Y2) & 0.898 & 62,983 & 0.000 \\
\hline Performance $5<-$ Performance (Y2) & 0.793 & 16.007 & 0.000 \\
\hline Performance6 <- Performance (Y2) & 0.771 & 25,368 & 0.000 \\
\hline Performance7 <- Performance (Y2) & 0.808 & 33,720 & 0.000 \\
\hline Performance 8 <- Performance (Y2) & 0.723 & 18,873 & 0.000 \\
\hline Performance9 <- Performance (Y2) & 0.763 & 26,331 & 0.000 \\
\hline Commitment $1<-$ Affective Commitment (Y1) & 0.801 & 22.186 & 0.000 \\
\hline Commitment $2<-$ Affective Commitment (Y1) & 0.795 & 14,464 & 0.000 \\
\hline Commitment3 <- Affective Commitment (Y1) & 0.869 & 43,661 & 0.000 \\
\hline Commitment $4<-$ Affective Commitment (Y1) & 0.869 & 57,253 & 0.000 \\
\hline Commitment5 <- Affective Commitment (Y1) & 0.853 & 54,688 & 0.000 \\
\hline Commitment6 <- Affective Commitment (Y1) & 0.837 & 25,812 & 0.000 \\
\hline Commitment7 <- Affective Commitment (Y1) & 0.801 & 35,590 & 0.000 \\
\hline Commitment $8<-$ Affective Commitment (Y1) & 0.749 & 18,292 & 0.000 \\
\hline Competency 2 <- Managerial Competence (X2) & 0.791 & 21.408 & 0.000 \\
\hline Competency $1<-$ Managerial Competence (X2) & 0.765 & 27,738 & 0.000 \\
\hline Competency $10<-$ Managerial Competence (X2) & 0.858 & 39,538 & 0.000 \\
\hline Competency $11<-$ Managerial Competence (X2) & 0.808 & 29.239 & 0.000 \\
\hline Competency $12<-$ Managerial Competence (X2) & 0.858 & $\mathbf{5 4 , 7 8 3}$ & 0.000 \\
\hline Competency3 <- Managerial Competence (X2) & 0.781 & 25,215 & 0.000 \\
\hline Competency4 <- Managerial Competence (X2) & 0.827 & 32.201 & 0.000 \\
\hline Competency 5 <- Managerial Competence (X2) & 0.813 & 27,926 & 0.000 \\
\hline Competency6 <- Managerial Competence (X2) & 0.729 & 15.606 & 0.000 \\
\hline Competency7 <- Managerial Competence (X2) & 0.807 & 33,595 & 0.000 \\
\hline Competency8 <- Managerial Competence (X2) & 0.876 & 51,417 & 0.000 \\
\hline Competency $9<-$ Managerial Competence (X2) & 0.771 & 14,833 & 0.000 \\
\hline
\end{tabular}

Source: SmartPLS 3.3.3 Output Data Processed, 2021

The $\mathrm{t}$-statistics value of the coefficient of the main path structural model (original sample O) Affective Commitment to Performance is $3.909>1.96$ (normal Z-score value for $=0.05$ ) and $\mathrm{P}$-value of $0.000<0.05$. This shows that Affective Commitment has a positive 
and significant effect on performance. So that the fifth hypothesis of the study which states that "Affective Commitment has a positive and significant influence on performance", is accepted. Meanwhile, the error term or model error in the three structural models is the level of inaccuracy in measuring the actual path coefficient value due to the fallibility of the measurement instrument (eg, an inappropriate Likert scale ), data entry errors or respondent errors. According to Hair et al. (2014), the error term is the difference in the path coefficient value between using data from the population (true value or parameter) and using data from the sample ( predicted value or statistics).

At the indicator level, the results of Bootstrapping for Estimating Path Coefficients and T-Statistics Total Effects from outer loading are presented in table 21.

Based on the Path Coefficient Estimation Table and Figure 2 Boostrapping Output, it is known that the t-statistics value of all indicators reflecting Organizational Culture, Managerial Competence, Affective Commitment, and Performance is greater than 1.96 with the p-value of all indicators less than 0.05 . This shows that all indicators of the variables of Organizational Culture, Managerial Competence, Affective Commitment, and Performance are significant, so that all of these indicators are truly able to reflect the variables studied.

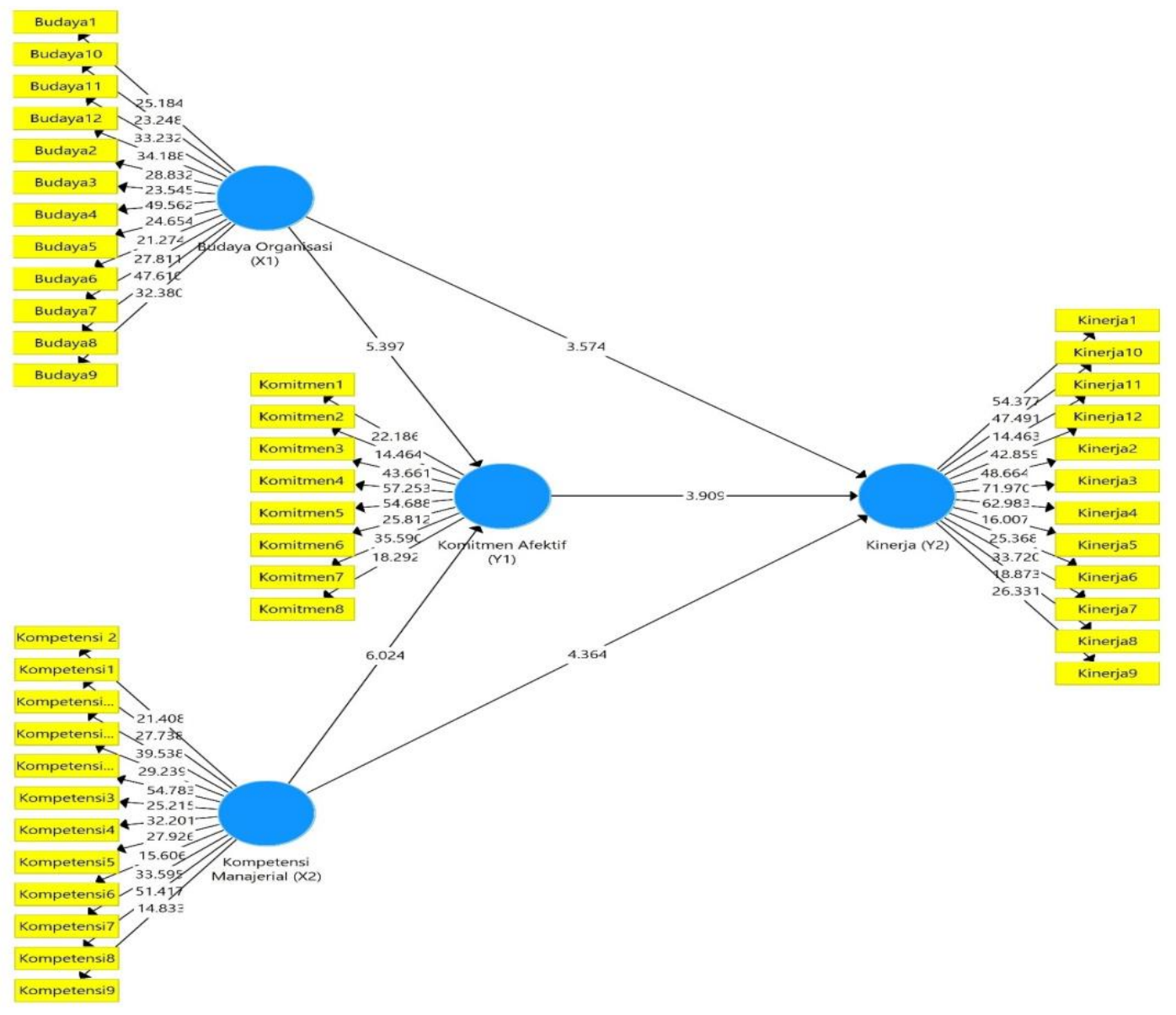

Figure 2: Bootstrapping Output; Source: SmartPLS 3.3.3 Output, 2021

If analyzed based on t-statistics and p-values, the items that most strongly reflect Organizational Culture include: Leadership in the company is considered an example of coordinating, organizing or running work units smoothly and efficiently (Culture4) with a tstatistic value of 49.562 and Togetherness in the company's emphasis on achievement and goal achievement (Culture8) with a tstatistics value of 47,610. Meanwhile, the weakest items reflecting Organizational Culture, among others: Company management is characterized by intense competition, high demands and achievement of work performance (Culture6) with a t-statistic of 21,274; and the Company emphasizes acquiring new resources and creating new challenges (Culture10) with a t-statistic value of 23,248.

Meanwhile, the items that most strongly reflect Managerial Competence include: The supervisor coordinates with the leaders of other work units within the company (Competency 12) with a t-statistics value of 54.78 and the supervisor motivates and encourages us to do a better job (Competence8) with the value of t-statistics is 51.417. While the weakest items reflecting Managerial Competence, among others: Supervisors consistently and regularly build relationships with internal and external clients (Competency9) with a tstatistics value of 14,833 and Supervisors work to improve the work processes used to achieve the desired results (Competency6) by the value of t-statistics is 15.606 . 
Meanwhile, the items that most strongly reflect Affective Commitment include: Feelings of the company being part of the family (Commitment 4) with a t-statistics value of 57,253 and Feelings of pleasure in completing the remaining work (Competency5) with a t-statistics value of 54.688. Meanwhile, the weakest items reflecting Affective Commitment include: There is an emotional bond with the company (Commitment 2) with a t-statistics value of 14,464 and Willingness to give all abilities to the company (Competence 8) with a t-statistics value of 18,292 .

Meanwhile, the items that most strongly reflect performance include: Products made according to the correct process (Performance3) with a t-statistics value of 71,970 and the Company delivering products on schedule (Performance4) with a t-statistics value of 62,983. Meanwhile, the weakest items reflecting performance include: The company conducts training and motivation for new and old employees (Kinerja11) with a t-statistics value of 14,463 and the Company has freedom in product innovation (Performance5) with a t-statistics value of 16.007 .

The findings of this study indicate that Affective Commitment has a positive effect on Performance, where the higher the Affective Commitment, the higher the Performance. This can be reinforced by statements from previous studies entitled Employeess' organizational commitment: its negative a aspectsffor organisasi "( Geneviciute k Janoniene \& Endriul aitiene, 2014) $\mathrm{c}$ which $\mathrm{n}$ says that the organizational commitment of employees have a positive influence on employee performance. So it can be interpreted that human resources that are supported by high commitment will tend to be more able to achieve the goals and values of the organization, by being willing to give more effort to the organization and trying to provide benefits to the organization.

\section{Mediation Test for the sixth hypothesis and the seventh hypothesis}

This study also discusses the indirect effect of organizational culture on organizational performance through affective commitment as a mediating variable. The results of the analysis of the direct influence, indirect effect, and total influence are presented in the output of Smart.PLS version 3.3.3 as presented in Table 22.

Table 22: Indirect Effect

\begin{tabular}{|c|c|c|c|}
\hline Relationship Between Variables & $\begin{array}{l}\text { Original } \\
\text { Sample (O) }\end{array}$ & $\begin{array}{l}\text { Tr Statistics } \\
(\mid \text { O/STDEV } \mid)\end{array}$ & P Values \\
\hline \multicolumn{4}{|l|}{ Indirect Influence } \\
\hline $\begin{array}{l}\text { Organizational Culture (X1) -> Affective Commitment (Y1) -> } \\
\text { Performance (Y2) }\end{array}$ & 0.109 & 2,896 & 0.004 \\
\hline $\begin{array}{l}\text { Managerial Competence (X2) -> Affective Commitment (Y1) -> } \\
\text { Performance (Y2) }\end{array}$ & 0.126 & 3,430 & 0.001 \\
\hline
\end{tabular}

\section{Source: SmartPLS 3.3.3 Output Data Processed, 2021}

Based on the Original Sample O, T-sttaistics, and P-values in Table 22 Special Effect Indirectly, it is known that the indirect influence of organizational culture on performance through Commitment Affective as an intervening variable of 0.109, where the indirect effect is much smaller than the influence Organizational culture directly to the performance of 0.259 . However, if the terms of the value of t-statistics which amounted to 2.896> 1.96 (normal Z-score value for $\alpha=0.05$ ) and a P-value of $0.004<0.05$, which means that the indirect effect has been positive and significant, show that Affective commitment proved to be an intervening variable that mediates the influence of organizational culture on performance. Hypothesis such that the six studies that claim that "organizational culture has a significant positive influence on performance through affective commitment", is accepted .

The total influence of Organizational Culture on Performance is 0.368 , which means, Organizational Culture has a significant positive direct influence on performance, the indirect influence of Organizational Culture on Performance through Affective Commitment makes the influence of Organizational Culture on Performance even greater. In addition, based on the Original Sample O, T-statistics, and P-value values in Table 5.21 specifically for Indirect Effects, it is known that the indirect effect of Managerial Competence on Performance through Affective Commitment as an intervening variable is 0.126 , where this indirect effect is more small compared to the direct influence of Managerial Competence on performance which is 0.376 . However, if viewed from the t-statistics value of $3.430>1.96$ (normal Z-score value for $=0.05$ ) and P-value of $0.001<0.05$, which means this indirect effect is positive and significant, shows that Affective Commitment is proven to be able to be an intervening variable that mediates the effect of Managerial Competence on Performance. So that the seventh hypothesis of research which states that "Managerial competence has a positive and significant influence on performance through affective commitment", is accepted .

The total influence of Managerial Competence on Performance is 0.501, which means, Managerial Competence has a significant positive direct influence on performance, the indirect influence of Managerial Competence on Performance through Affective Commitment makes the influence of Managerial Competence on Performance even greater.

The findings in this study state that organizational culture has a positive and significant influence on performance through affective commitment. Organizational commitment mediates the influence of organizational culture on performance, this means that organizational commitment is needed because it can increase the influence of organizational culture on performance. The results of 
this study are consistent with Patulak et al . (2013) concluded that there is a positive and significant influence between organizational culture on employee performance mediated by organizational commitment. Adi (2013) and Hakim (2015) stated that there is a positive and significant influence between organizational culture on employee performance mediated by organizational commitment. A strong organizational culture, besides being able to directly affect performance, can also foster high organizational commitment so that with this commitment, it will also have implications for improving performance.

The findings of the study indicate that Managerial Competence has a positive and significant influence on performance through affective commitment. The results of this study are consistent with Haryanti and Cholil (2014) showing that however high competence of employees indicated by indicators of knowledge, skills and attitudes directly affects improvement performance, but mediated by high organizational commitment which is characterized by continuation indicators, where employees feel they have a high responsibility to remain in the organization and feel lost if they do not perform the tasks as their responsibilities, have a significant impact in improving employee performance.

\section{Conclusions}

In the diagram above, it can be seen that the organizational culture of the food and beverage industry players in Jambi Province is the clan type. According to Cameron and Quinn (2011), the type of clan culture focuses on the direction of the organization and has flexibility to the values adopted in the organization. The main characteristic of this type of culture is the relationship between members of the organization which is based on a sense of kinship, togetherness and carries a high spirit of loyalty. The family atmosphere is clearly reflected in the comments of one respondent, namely the business owner and his employees have a family relationship such as: cousins, nephews or other relatives.

But on the other hand, sometimes the great sense of kinship creates some negative sides from the side of law enforcement. Employees' concerns about weak actions and sanctions for violations. Research on aspects of organizational culture is expected to show that food and beverage industry players desire that the dominance of the clan culture type is maintained. These results are in accordance with the opinion of the respondents, namely "family culture must be maintained, a sense of kinship is very important to increase cohesiveness. However, the close sense of kinship in the food and beverage industry also needs to be managed properly. Respondents stated, "there is still a personal interest in the company". Another respondent argued, "it is better if the excessive family culture is removed, because it can be misused by business actors". Hendarman (2012) suggests that in some cases, managers delegate too heavy a workload to their subordinates, while the manager can relax. The close sense of kinship can be balanced with a clear and formalized work system.

This study also found that the organizational culture of the adhocracy type and the hierarchy adopted by the food and beverage business actors received a small portion, this is because the hierarchy type has strict control, strong stability and efficiency through a formal system, besides that the adhocracy culture type is characterized by taking risk and flexibility in innovation are temporary, this is in contrast to food and beverage business actors whose operations are carried out in a simple manner and employees also have kinship and family relationships whose tolerance is higher compared to other types of culture.

\section{Recommendations}

Based on the results of this study, future research agendas that need to be suggested to further researchers are as follows:

i. This study uses organizational culture and managerial competence variables developed by Cameron and Quinn, in analyzing data not using OCAI (Organizational Culture Assessment Instrument) and MSAI (Management Skill Assessment Instrument), due to organizational culture and managerial competence variables only taking some of the dimensions and indicators are adapted to the character of the food and beverage industry players in Jambi Province, in addition there are additional variables of affective commitment and performance as well as in analyzing data using SEM PLS, meaning that further researchers can try to apply OCAI (Organizational Culture Assessment Instrument) and MSAI ( Management Skill Assessment Instrument) in the food and beverage industry.

ii. The effect of organizational culture, managerial competence and affective commitment on organizational performance based on the results of this study is about $71.8 \%$. That is, there is $28.2 \%$ of the influence of other factors not examined in this study, namely normative commitment and continual commitment, besides that in measuring the performance of the food and beverage industry, other methods can also be used such as Implementation of the Balanced Scorecard, Organizational Performance Measurement (OPM), Integrated Performance Measurement Systems (IPMS).

iii. In this study, there were only four components studied, namely organizational culture, managerial competence, affective commitment and performance. Meanwhile, recent studies have also found that there are other dimensions that can measure organizational performance. For this reason, it is recommended that in research with the context of the food and beverage industry it is necessary to pay attention to other aspects besides the four aspects to be used as further research to explain organizational performance. Likewise with the mediating factor in this study, only the affective commitment factor was studied. It is recommended that further researchers pay attention to other mediating factors that may mediate the relationship between organizational culture and managerial competence with organizational performance.

iv. This research focuses on the food and beverage industry in Jambi Province. Research with the same variables can also be carried out in other provinces. Considering that the food and beverage industry is also found in other areas outside Jambi 
Province. The focus of this research is also small organizations. Considering that small organizations or IKMs have various kinds outside the food and beverage industry, it is also necessary to conduct similar research in the context of SMEs outside the food and beverage industry.

Author Contributions: Conceptualization, SA, SS, E, SA.; Methodology, SA, SS, E, SA.; Data Collection, SA, SS, E, SA.; Formal Analysis, SA,SS, E, SA.; Writing — Original Draft Preparation, SA,SS, E, SA.; Writing—Review And Editing, SA,SS, E, SA.; All authors have read and agreed to the published the final version of the manuscript.

Institutional Review Board Statement: Ethical review and approval were waived for this study, due to that the research does not deal with vulnerable groups or sensitive issues.

Data Availability Statement: The data presented in this study are available on request from the corresponding author. The data are not publicly available due to privacy.

Conflicts of Interest: The authors declare no conflict of interest.

\section{References}

Albrecht, Simon L, (2010), Handbook of Employee Engagement Perspective, Issues, Research and Practice, New Horizons in Management, Series Editor; Cary L Cooper, CBE, Distinguished Professor of Organizational Phsychology and Health, Lancester University, UK

Arifin, A. (2020). Pengaruh Budaya Organisasi dan Lingkungan Kerja terhadap Kepuasan Kerja Dan Kinerja Karyawan Industri Terasi Di Kabupaten Sumenep. Jurnal Ilmiah Mahasiswa Ekonomi Manajemen, 5(3).

Anand, B.(2013), Managerial Competencies and Their Influence on Managerial Performance, International Journal of Advanced Research in Management and Social Science, 5(2).

Allen, N. J., \& Meyer, J. P. (1990). The measurement and antecedents of affective, continuance and normative commitment to the organization. Journal of occupational psychology, 63(1), 1-18.

Addy, C., Pearce, J.\& Bennett, J. (1994). Performance Measures In Small Manufacturing Enterprises ; Are Firms Measuring What Matters.

Andersen, H., Cobbold, I., Lawrie, G., House, A. \& Street, M. (2001) Balanced Scorecard implementation in SMEs: reflection in literature and practice.

Arsyad, L. 2000. Pengantar Perencanaan dan Pembangunan Ekonomi Daerah. Badan Penerbit Fakultas Ekonomi (BPFE).Yogyakarta

Aritonang, L.R. (2005). Kepuasan pelanggan: Pengukuran dan penganalisisan dengan SPSS. Jakarta : PT Gramedia Pustaka Utama.

Armstrong, M. \& Baron, A. (2007). Human Capital Management: Achieving Added Value Through People, Great Britain and the United States in 2007 by Kogan Page Limited.

Babbie, E, (2014), The Basics of Social Research, Sixth Edition, International Edition, Wadswoth Publishing, Co, Inc

Badan Pusat Statistik Provinsi Jambi (2019), Profil Industri Mikro dan Kecil Provinsi Jambi, No.Katalog : 6104006.15.

Bambang Purwanto, H., \& Soliha, E. (2017). Pengaruh karakteristik pekerjaan dan kompetensi terhadap kinerja melalui komitmen organisasional. Jurnal Manajemen, 21(2), 227-240.

Barnes, M., Coulton, L., Dickinson, T., Dransfield, S., Field, J., Fisher, N., Saunders, I. \& Shaw, D. (1998) A new approach to performance measurement for small and medium enterprises. Performance Measurement-Theory and Practice, University of Cambridge, 14-17.7.

Berrio, A.A. (2003). An organizational culture assessment using the competing values framework: A profile of Ohio State University Extension. Journal of Extension, Vol 41. Maret 14, 2012. http://www.joe.org/joe/2003april/a3/php

Bohm, D. (1994) Thought as a System, Psychology Press.

Cameron, K.S., \& Quinn, R.E. (2006). Diagnosing and changing organizational culture : Based on competing values framework. San Fransisco: Addison-Wesley.

Cartwright, J. (1999). Cultural transformation: Nine factors for improving the soul of your business. London: Prentice Hall.

Chennell, A. F., Dransfield, S., Field, J., Fisher, N., Saunders, I. \& Shaw, D. (2000) OPM : a system for organisational performance measurement. Proceedings of Performance Measurement : Past, Present and Future,19-21.

Cocca, P. \& Alberti, M. (2010) A framework to assess performance measurement systems in SMEs. International Journal of Productivity and Performance Management, 59, 186-200.

Colquitt, LePine, Wesson, (2015). Organizational Behavior : Improving Performance and Commitment in the Workplace, Fourth Edition, McGraw Hill Education, 2, Pen Plaza, New York.

Cooper, R. \& Kaplan, R. S. (1991) Profit priorities from activity-based costing. Harvard Business Review, 69, 130-135

Dwi Gemina, D., \& Ginanjar, A. (2019). Kinerja usaha miro kecil menengah makanan Kabupaten Cianjur berbasis komitmen, kompetensi dan motivasi usaha. Jurnal Visionida, 5(2), 1-12.

David, F.R. (2002). Manajemen strategis: Konsep. (Alexander Sindoro, Penerjemah). Jakarta: Prenhallindo.

Daud, S. (2011). Pacto on the move. Pacto Newsflash, 1. Deal, T.E., \& Kennedy, A.A. (2000). Corporate culture. Massachussets: Perseus Publishing. 
Dessler, Gary, (2011), Manajemen Sumberdaya Manusia, edisi ke-10, Jakarta, PT.Indeks

Dharma, S. (2002). Transformasi organisasi menggunakan pendekatan 4R. Usahawan, 4, 11-15.

Dinas Perindustrian dan Perdagangan Provinsi Jambi, 2020

Dowling, Peter J, Festing, Marion, Engle, Allen D Sr, (2013) International Human Resource Management, $6^{\text {th }}$ edition, Cengage Learning EMEA.

Dori, M.A. (2012). Industri MICE tumbuh kian mekar. 17 April 2012. http://industri.kontan.co.id/news/industri-mice-tumbuh-kianmekar

Eccles, R. G. (1991) The Performance Measurement Manifesto. Harvard Business Review, 69, 131-137.

Elabe, Pinti, E. (2013). Pelaksanaan Penjualan Konsinyasi dalam Mengembangkan Usaha pada Industri Kecil dan Menengah (IKM) Pangan Kota Pekanbaru Ditinjau menurut Ekonomi Islam (Doctoral dissertation, Universitas Islam Negeri Sultan Syarif Kasim Riau).

Ernowo, P. (2012a, Februari 29). Banyak pameran, industri MICE Indonesia terus berkembang. 17 April 2012. http://travel.okezone.com/read/2012/02/29/407/584553/banyak eventwisata-mice-indonesia-terus-berkembang

Ernowo, P. (2012b, Maret 6). Pariwisata dunia melaju kencang, Indonesia makin pede. 17 April 2012. http://travel.okezone.com/read/2012/03/06/407/587923/pariwisata-duniamelaju-kencang-indonesia-makin-pede

Espejo, R., Schuhmann, W., Schwaninger, M., \& Biliello, U. (1996). Organizational transformation and learning: A cybernatic approach to management. San Fransisco: Wiley, John \& Sons Inc.

Flamholtz, E.G., \& Randle, Y. (1998). Changing the game: Organizational transformations of the first, second and third kinds. New York: Oxford University Press.

Fransen, Jan and Pahala H.L. Gaol, (2016), Absorptive capacity and local networking of home-based enterprises in 'Kampong Cyber', Yogyakarta, Indonesia, Local governance, economic development and institutions. Palgrave Macmillan: Hampshire, pp. 292-312.

Garengo, P., Biazzo, S., Bititci, U. S. \& Venezia, V. (2005) Performance measurement systems in SMEs: a review for a research agenda. International Journal of Management Reviews, 7, 25-47.

Garengo, P. \& Bititci, U. (2007) Towards a contingency approach to performance measurement: an empirical study in Scottish SMEs. International Journal of Operations \& Production Management, 27, 802-825.

Geneviciute, Janoniene \& Endriul aitiene, (2014).Employees' Organizational Commitment: Its Negative Aspects for Organizations, Procedia - Social and Behavioral Sciences,Volume 140, 22 August 2014,Pages 558-564

Ghozali, I. (2005). Aplikasi analisis multivariate dengan program SPSS. Semarang: Badan Penerbit Universitas Diponegoro.

Gibson, J.L., Ivancevich, J.M., Donnelly Jr, J.H., \& Konospake, R. (2006). Organizations: Behavior, structure, process (12th ed.). Singapore: McGraw-Hill.

Gorry, G. A. \& Morton, M. S. S. (1971) A framework for management information systems. Sloan management review, 13 , 55-70.

Greenberg, J. \& Baron, R. A. (2010). Behavior in organizations. $10^{\text {th }}$ Edition. New Jersey: Prentice Hall International, Inc.

Hair, B., Babin, A. (2009), Multivariate Data Analysis, $4^{\text {th }}$ ed, Englewood Cliffs, New Jersey, Prentice Hall International Inc.

Hendarman, B. (2012). Personal interview. Staf senior PT. Pactoconvex Niagatama.

Huan, T.C. (2007). Executive learning exercise and trainer's notes for importance-performance analysis (IPA): Confronting validity issues. International Journal of Culture, Vol 1, 315-327.

Hudson, M., Lean, J., Smart, P. A. (2001). Improving Control through Effective Performance Measurement in SMEs. Production Planning \& Control, 12, 804-813.

Hudson, M., Smart, A. \& Bourne, M. (2001). Theory and practice in SME performance measurement systems. International Journal of Operations and Production Management, 21, 1096-1115.

Hudson S., M. \& Smith, D. (2007). Implementing strategically aligned performance measurement in small firms. International Journal of Production Economics, 106, 393-408.

Hvolby, H. H. \& Thorstenson, A. (2001). Indicators for performance measurement in small and medium-sized enterprises. Proceedings of the Institution of Mechanical Engineers, Part B: Journal of Engineering Manufacture, 215, 1143-1146.

Ivancevich, John M; Konopaske, Robert;Matteson, Michael T, (2011), Perilaku dan Manajemen Organisasi, edisi ke-7, Jakarta, Erlangga.

J. Stanworth, J., \& Purdy, J. (2006). SME Facts and Issues: A Compilation of Current Data and Issues on UK Small and Medium Firms. Small Enterprise Research Team, Open University Business.

Jarvis, R., Curran, J., Kitching, J. \& Lightfoot, G. (2000). The use of quantitative and qualitative criteria in the measurement of performance in small firms. Journal of small business and enterprise development, 7, 123-134.

Jatmiko, Rohmat Dwi, (2014). Pengaruh Budaya Organisasi Terhadap Kinerja Usaha Kecil, Jurnal Of Management And Business Review, 11(1),1-19.

Marijan, K. (2005). Mengembangkan industri kecil menengah melalui pendekatan kluster. dalam Jurnal INSAN, 7(3).

Kaplan, R. S. (1993). Building a Balanced Scorecard. Harvard Business Review, 71, 138.

Kaplan, R. S. \& Norton, D. P. (2006). Alignment Using the Balanced Scorecard to CreateCorporate Synergies, Boston, Harvard Business School Publishing Corporation.

Kaplan, R. S., Norton, David P. (1992). The Balanced Scorecard - Measures that Drive Performance. Harvard Business Review, 70 , 71-79. 
Kaplan, R. S., Norton, David P. (1996). Translating Strategy into Action, The Balanced Scorecard, Boston, Harvard Business School Press.

Kennerley, M. \& Neely, A. (2003). Measuring performance in a changing business environment. International Journal of Operations \& Production Management, 23, 213-229.

Kemendagri. (2011). Warta ekspor: Potensi industri MICE Indonesia. Jakarta: Tim redaksi.

Kesrul (2004). Meeting incentive trip conference exhibition. Yogyakarta: Graha Ilmu.

Kinicki, K. (2005). Perilaku Organisasi, Buku 1 dan 2, Jakarta, Salemba Empat.

Kinicki, K., Sinding, Waldstrom, (2014). Organizational Behaviour, McGraw Education.

Kolb, D.A., Rubin, I.M., \& Osland, J.S. (2007). The organizational behavior reader (8th ed.). New Jersey: Prentice Hall Inc.

Kotter, J. P. (1996). Leading change. Boston: Veritas Press.

Kotter, J.P., \& Heskett, J.L. (1992). Corporate culture and performance. New York: The Free Press.

Kreitner, Robert \& Kinichi, Anggelo, (2014). Perilaku Organisasi, Edisi ke-9, Jakarta, Salemba.

Laitinen, E. K. (1999). A dynamic performance measurement system: evidence from small Finnish technology companies. Scandinavian Journal of Management, 18, 65-99.

LIPI, (2020). Survei Kinerja UMKM di Masa Pandemi COVID19,Lembaga Ilmu Pengetahuan Indonesia, Juni 2020

Luthans, F. (1992). Organizational behavior (6th ed.). Singapore: McGraw-Hill.

Malhotra, N.K. (2010). Marketing research: An applied orientation (6th ed.). New Jersey: Pearson.

Manville, G. (2007). Implementing a balanced scorecard framework in a not for profit SME. International Journal of Productivity and Performance Management, 56, 162-169.

Miller, F.A., \& Katz, J.H. (2002). The inclusion breakthrough. San Fransisco: Berrett-Koehler Publisher, Inc.

Mintzberg, H. (1998a). Strategy.

Mintzberg, H. (1998b) .Strategy safari: a guided tour through the wilds of strategic management / Henry Mintzberg, Bruce Ahlstrand, Joseph Lampel, New York, Free Press.

Mintzberg, H. (2000). The rise and fall of strategic planning, Pearson Education. Mitzberg, H. (1994) The Rise and fall of Strategic Planning, Hertfordshire, Prentice Hall International (UK) Limited.

Mitzberg, H., Quinn, James Brian., Ghoshal, S. (1999). The StrategyProcess, Harlow, Prentice Hall Europe.

Mc Adam, R. (2000). The implementation of reengineering in SMEs: A grounded study.International Small Business Journal, 18, 29.

Mc Adam, R. \& Mcenroe, C. (2004). A framework for measuring quality improvement in Irish supplier SMEs: a multiple case analysis. International Journal of Business Performance Management, 6, 171-188.

Moorhead, G., \& Griffin, R.W. (2013). Organizational behavior: Managing people and organizations (11th ed.). Boston: Houghton Mifflin Company.

Nanriana, A. (2012). Personal interview. Staf PT. Pactoconvex Niagatama.

Neely, A., Adams, C.., Kennerly, M. (2002). The Performance Prism, Edinburgh Gate, Harlow CM20 2JE., Pearson Education Ltd.

Neely, A., Gregory, M. \& Platts, K. (2005). Performance measurement system design: a literature review and research agenda. International Journal of Operations \& Production Management, 25, 1228-1263.

Neely, A., Marr, B., Roos, G., Pike, S. \& Gupta, O. (2003). Towards the third generation of performance measurement. Controlling, 15, 129-135.

Neumann W.L. (2003). Social research methods: Quantitative and qualitative approaches. Boston: Allyn and Bacon.

Nudurupati, S. S. \& Bititci, U. S. (2005). Implementation and impact of IT-supported performance measurement systems. Production Planning \& Control, 16, 152-162.

Nudurupati, S. S., Bititci, U. S., Kumar, V. \& Chan, F. T. S. (2011). State of the art literature review on performance measurement. Computers \& Industrial Engineering.

Pendit, N. (1999). Wisata konvensi: Potensi gede bisnis besar. Jakarta: PT Gramedia Pustaka Utama.

Peraturan Pemerintah Nomor 32 Tahun 1998 tentang Pembinaan dan Pengembangan Industri Kecil.

Pierce, J.G. (2004). Organizational culture and professionalism: An assessment of the professional culture of the U.S. army senior level officer corps. Disertasi The Graduate School of Public Affair, The Pennsylvania State University.

Prasetyo, B., \& Jannah, L.M. (2005). Metode penelitian kuantitatif: Teori dan aplikasi. Jakarta: Raja Grafindo Persada.

Qomaruzzaman (2008). Implementasi dan asesmen perubahan budaya perusahaan PT.Pupuk Kalimantan Timur. Tesis Magister Manajemen Fakultas Ekonomi Universitas Indonesia.

Ratna Evy, dkk,(2005). Usaha Industri dan Kerajinan di Indonesia, (Jakarta: Bumi Aksara,2005), Cet. Ke-1, h. 8.

Rivai, Ahmad (2014). Skripsi, Pengaruh Kompetensi Manajerial Pengusaha Terhadap Kinerja Usaha Pada Sentra Umkm Pengrajin Logam Dan Onderdil Citeureup Bogor, Program Studi Ilmu Administrasi Bisnis Fakultas Ilmu Sosial dan Ilmu Politik Universitas Padjadjaran,

Rochim. A Sidik, Sutoyo (2020). Analisis Kepemimpinan Transformasional, Komitmen Dan Budaya Organisasi Terhadap Kinerja Pegawai Pt. Angkasa Pura I (Persero) Di Masa Pandemi Covid 19, Jurnal Manajemen Bisnis, Volume 5, nomor 1, juli 2020, pp.69-79. 
Rosita, Sry, (2018). Kontrak Psikologis Dalam Meningkatkan Organizational Citizenship Behavior Dengan Sikap Kerja Sebagai Variabel Mediator Pada Badan Usaha Milik Negara (BUMN) di Provinsi Jambi, Disertasi Program Doktor Ekonomi Pascasarjana Universitas Jambi.

Robbins, S.P. (2017). Organizational behavior. New Jersey : $16^{\text {th }}$ edition, Prentice Hall International, Inc.

Robbins, S.P., \& Judge, T.A. (2009). Organizational behavior. New Jersey: Prentice Hall.

Rolland Epafras Panngidae, (2016). Pengaruh Budaya Organisasi Terhadap Komitmen Organisasional Dosen Melalui Spiritualitas di Tempat Kerja, Motivasi Dosen dan Kepuasan Kerja Dosen, Disertasi, Program Studi Doktor Ilmu Manajemen, Fakultas Ekonomi dan Bisnis, Universitas Padjadjaran, Bandung.

Satrya, D.G. (2012). Keampuhan MICE dan kesiapan daerah. 18 April 2012.http://www.bandungmedia.com/interaksi/opini/201201/keampuhanmice-_dan-kesiapan-daerah/

Samad, S., Anuar, A. M., \& Ahmed, W. A. (2014). Australian Journal of Basic and Applied Sciences The Impact of Organizational Culture on Organizational Performance. Australian Journal of Basic and Applied Sciences, 7(14), 442-449.

Shahzad, F., Luqman, R. A., Khan, A. R., \& Shabbir, L. (2012). Impact of Organizational Culture on Organizational Structure. Ekonomika, Journal for Economic Theory and Practice and Social Issues, 3(9), 975- 985.

Schein, E. (2010). Organizational culture and leadership (4th ed.). San Fransisco: Jossey-Bass.

Siagian, D., \& Sugiarto (2000). Metode statistika untuk bisnis dan ekonomi. Jakarta : PT Gramedia Pustaka Utama.

Simarmata, J. (2021). Disertasi : Praktek MSDM Dalam Meningkatkan Kinerja Organisasi Dengan Human Capital Dan Kinerja Individu Sebagai Variabel Mediasi Pada Industri Batik Jambi, Program Doktor Ilmu Ekonomi, Universitas Jambi.

Siregar, D. S. (2003). Diagnosis perubahan kultur organisasi dalam rangka transformasi organisasi: Studi kasus pada kantor pusat PT. Kereta Api Indonesia (Persero). Tesis Pasca Sarjana Fakultas Ilmu Sosial dan Ilmu Politik Universitas Indonesia.

Situngkir, S. (2005), Pengaruh Budaya Organisasional, Kepemimpinan Visioner, dan Komitmen Organisasional Terhadap Kepuasan Kerja dan Kinerja Manajer serta Dampaknya Pada Kinerja Perbankan (Bank Umum di DKI Jakarta), Disertasi, Program Pascasarjana Universitas Padjadjaran, Bandung.

Spencer, L. \& Spencer, S. (1993). Competence at Work : Models for Superior Performance. New York: John Wiley \& Sons, Inc.

Sugiantoro, B. (2012). Diagnosis Budaya Organisasi dan Kompetensi Manajerial di PT. Pactoconvex Niagatama. Tesis Fakultas Ekonomi Program Studi Magister Manajemen, Universitas Indonesia.

Sugiwardani, R.M. (2012). Personal interview. Business Development Manager PT. Pactoconvex Niagatama.

Suri, R. (1998). Quick response manufacturing: a companywide approach to reducing lead times, Productivity Pr.

Suryani, D.T. (2012). Personal interview. Human Resources Director PT.Pactoconvex Niagatama.

Taticchi, P., Cagnazzo, L., Botarelli, M. \& Sameh, M. (2009a) Performance measurement: discussion of the literature available for large companies and SMEs.

Taticchi, P., Tonelli, F. \& Cagnazzo, L. (2009b) Development of a performance measurement system: case study of an Italian SME. World Scientific and Engineering Academy and Society (WSEAS).

Taticchi, P., Tonelli, F. \& Cagnazzo, L. (2010) Performance measurement and management: a literature review and a research agenda. Measuring Business Excellence, 14, 4-18.

Taticchi, P. A. O. L. O., Tonelli, F. L. A. V. I. O., Sameh, M. O. H. A. M. E. D., \& Botarelli, M. (2008). Performance measurement and management: what is next?. WSEAS, Transaction On Business and Economics, 5(11), 497-506.

Umar, H. (2002). Metode Riset Bisnis. Jakarta: PT Gramedia Pustaka Utama.

Urata, S. (2000). Policy Recommendation for SME Promotion in The Republic of Indonesia. JICA Report. Jakarta.

Untari, R, (1998). Analisis Spasial Lokasi Industri Kecil di Semarang, Lemlit Unika Sugijapranata, Semarang, Penelitian tidak dipublikasikan

Veriyanto A. P., Ni Made D. R., Igam A. D. P. (2017). Pengaruh Kompetensi Dan Budaya Organisasi Pada Kinerja Penyusun Laporan Keuangan Satuan Kerja Melalui Komitmen Organisasi, Fakultas Ekonomi dan Bisnis Universitas Udayana, Bali, Indonesia

Vos, E. \& Roulston, C. (2008). SME Owner Involvement and Business Performance: Financial Security Rather Than Growth. Small Enterprise Research, 16, 70-85.

Wagner, J.A, Hollenbeck, J. R (2010). Organizational Behavior: securing competitive advantage, $5^{\text {th }}$ ed, 2005. Routledge is an Imprint of the Taylor and Francis Group, an Informa Business.

Wibowo (2011). Budaya organisasi: Sebuah kebutuhan untuk meningkatkan kinerja jangka panjang. Jakarta: Raja Grafindo Persada. Widyastuty, (2007). Pengaruh Insentif terhadap Prestasi Kerja Pegawai, Tesis, UNAIR.

Wilson B.Eng, Cathal, (2013). Dominant Operational Performance Measures for SME Owner Managers, Dessertation, University of Limerick.

Wood, J.M., Wallace, J., Zeffane, R.M., Kennedy, D.J., Schermerhon, J.R., Hunt, J.G., \& Osborn, R.N. (1998). Organizational behaviour: An Asia-Pacific perspective. Brisbane: Jacaranda Wiley.

Yayik Novitriami, Dicky Hastjarjo T, (2015). Meningkatkan Komitmen Afektif melalui Cerita Sukses Organisasi, Gadjah Mada Journal Of Professional Psychology, 1(1), 18-32

Zikmund, B., C., Griffin, (2009). Business Research Methods, $8^{\text {th }}$ Edition, South Western College Pub.

Zwell, M. (2000). Creating a culture of competence. New York: John Wiley \& Sons, Inc. 
Zibang, M., S., (2019). Pengaruh Modal Sosial, Modal Manusia, Budaya Kerja Dan Pemberdayaan Terhadap Kinerja Pelaku Usaha Industri Tenun Songket Di Kecamatan Jonggat Kabupaten Lombok Tengah, Tesis, Program Studi Magister Ilmu Ekonomi Fakultas Ekonomi Dan Bisnis Universitas Udayana Denpasar.

Zulkarnain (2001). Membangun Ekonomi Kerakyatan, (Pekanbaru: Unri Press, 2001), h. 149

Publisher's Note: SSBFNET stays neutral with regard to jurisdictional claims in published maps and institutional affiliations.

\section{(c) (1)}

(c) 2021 by the authors. Licensee SSBFNET, Istanbul, Turkey. This article is an open access article distributed under the terms and conditions of the Creative Commons Attribution (CC BY) license (http://creativecommons.org/licenses/by/4.0/).

International Journal of Research in Business and Social Science (2147-4478) by SSBFNET is licensed under a Creative Commons Attribution 4.0 International License. 